\title{
Treatment of a forelimb fracture and rehabilitation of a free-ranging Iberian Wolf (Canis lupus signatus) ${ }^{1}$
}

\begin{abstract}
Filipe C. Silva ${ }^{3,2}$, Roberto F. Sargo ${ }^{4}$, Luís C. Sousa ${ }^{4}$, Helena Rio-Maior ${ }^{5,6}$, Ricardo
Brandão $^{7}$, Nuno Santos ${ }^{8}$, Francisco Álvares ${ }^{5,6}$ and Isabel R. Dias ${ }^{2,8,9 *}$

ABSTRACT.- Silva F.C., Sargo R.F., Sousa L.C., Rio-Maior H., Brandão R., Santos N., Álvares F. \& Dias I.R. 2016. Treatment of a forelimb fracture and rehabilitation of a free-ranging Iberian Wolf (Canis lupus signatus). Pesquisa Veterinária Brasileira 36(5):412-416. Departamento de Ciências Veterinárias, Escola de Ciências Agrárias e Veterinárias Universidade de Trás-os-Montes e Alto Douro, Cx. Postal 1013, Vila Real, 5000-801, Portugal. Email: idias@utad.pt

The surgical treatment of an exposed compounded comminuted fracture of the right radius and ulna in a free-ranging adult female Iberian Wolf (Canis lupus signatus) with an osteosynthesis plate and screws and subsequent post-operative care are described. The evolution of the fracture healing was very similar to those expected in a dog of the same size. The prompt surgical intervention and a proper housing, feeding and wound management adapted to a free-ranging wolf, in view to reduce manipulation and post-operative complications, allowed the subsequent rehabilitation and release of the animal. After $10^{\text {th }}$ post-operative weeks the wolf was fitted with a Global Positioning System (GPS) for wildlife tracking collar and released in the same area where it has been caught. GPS telemetry data showed that the animal covered increasingly large distances confirming a complete functionality of the right thoracic limb and its successfully return to the wild. This report could constitute the first detailed report of a long bone fracture treatment in a free-ranging wolf and its successfully rehabilitation, release and adaptation to the wild.
\end{abstract}

INDEX TERMS: Iberian Wolf, Canis lupus signatus, radius, ulna, fracture, osteosynthesis, rehabilitation.

\footnotetext{
${ }^{1}$ Received on April 15, 2015.

Accepted for publication on February 23, 2016.

${ }^{2}$ Departamento de Ciências Veterinárias, Escola das Ciências Agrárias e Veterinárias, Universidade de Trás-os-Montes e Alto Douro, Quinta de Prados, Vila Real, 5000-801, Portugal. *Corresponding author: idias@ utad.pt

${ }^{3}$ Centro de Investigação em Ciência Animal e Veterinária (CECAV), Universidade de Trás-os-Montes e Alto Douro, Quinta de Prados, Vila Real, 5000-801, Portugal.

${ }^{4}$ Hospital Veterinário, Universidade de Trás-os-Montes e Alto Douro, Quinta de Prados, Vila Real, 5000-801, Portugal.

${ }^{5}$ Centro de Investigação em Biodiversidade e Recursos Genéticos (CIBIO/InBio), Universidade do Porto, Campus Agrário de Vairão, Vairão, 4485-661, Portugal.

${ }^{6}$ Equipa de Investigação do Lobo Ibérico (Iberian Wolf Research Team (IWRT).

${ }^{7}$ Aldeia/Cervas, Apartado 126, Gouveia, 6290-909, Portugal.

${ }^{8}$ Instituto para as Ciências da Vida e da Saúde/3B's (ICVS), Escola das Ciências da Vida, Universidade do Minho, Campus de Gualtar, Braga, 4710057, Portugal.

${ }^{9}$ Centro para a Investigação e Tecnologia em Ciências Agro-Ambientais e Biológicas (CITAB), Universidade de Trás-os-Montes e Alto Douro, Quinta de Prados, Vila Real, 5000-801, Portugal.
}

RESUMO.- [Osteossíntese de fratura localizada no membro torácico num Lobo Ibérico (Canis lupus signatus) selvagem e sua reabilitação.] 0 objetivo do presente artigo é a descrição da realização da estabilização de uma fratura cominutiva exposta do rádio e ulna do membro torácico direito em Lobo Ibérico selvagem por meio de osteossíntese com placa e parafusos ósseos bem como o manejo pós-operatório. A evolução da cicatrização da fratura óssea foi similar à esperada num canídeo doméstico de porte idêntico. A intervenção cirúrgica realizada rapidamente, bem como o alojamento adequado, alimentação e manejo adaptado a um lobo selvagem, visando minimizar a manipulação e o aparecimento de possíveis complicações pós-operatórias permitiram o sucesso na reabilitação e posterior libertação do animal. Na 10a semana pós-operatória foi colocado um colar GPS no animal para deteção permanente da sua localização, tendo sido o animal libertado na mesma área onde havia sido capturado. Os dados obtidos por telemetria GPS demostraram que o lobo percorreu distâncias consideráveis, confirmando a completa 
recuperação do membro torácico direito e o sucesso da sua reintrodução na natureza. Este artigo poderá constituir a primeira descrição pormenorizada sobre a estabilização de fratura de ossos longos em um lobo selvagem com a sua posterior reintrodução na vida selvagem com sucesso.

TERMOS DE INDEXAÇÃO: Lobo Ibérico, Canis lupus signatus, rádio, ulna, fratura, osteossíntese, reabilitação.

\section{INTRODUCTION}

The Iberian Wolf Canis lupus signatus (Cabrera 1907) is a subspecies of grey wolf slightly smaller $(140 \mathrm{~cm}$ length, $70-$ $80 \mathrm{~cm}$ height, $35-55 \mathrm{~kg}$ weight) than the ones from northern latitudes (Álvares 2004), currently mainly restricted to northern Portugal and northwestern Spain and estimated in approximately 2000 individuals, from which about $80 \%$ occurs in Spain and 20\% in Portugal (Blanco et al. 2009). In Portugal, the wolf is fully protected by both national and international legislation and listed as "Endangered" (Álvares 2004).

However, as in most of their worldwide range, wolves in Portugal still suffer a high illegal mortality due to human-related causes as a result of conflict with human interests motivated by frequent depredation on livestock (Álvares 2004). The high conservation value of this carnivore is also enhanced by the existence of isolated and small population nuclei, where rescuing potential breeding adults can be crucial to assure long-term population viability.

Bone fractures in wolves can be caused by natural causes (ex. prey-inflicted injuries), and mainly by human-related activities (ex. traffic accidents, illegal trapping) or captures for scientific purposes (Mech \& Boitani 2003, Arnemo et al. 2006, Frame \& Meier 2007), which could lead to the animal death or to a limited locomotor functionality, especially in bone limbs which can hamper the wolf biological requirements for covering wide ranges and hunt large prey. However, there are studies based on osteological collections from free-ranging wolves demonstrating successful ossification of old fractures (Wobeser 1992, Kreeger 2003).

As there are few data published concerning traumatic skeletal lesions and their treatment in wolves (Bush et al. 1975, Kielbowicz et al. 2003), in this case report, a thoracic limb fracture repair in a free-ranging Iberian Wolf is presented with its successful rehabilitation and release into the wild.

\section{CASE REPORT}

A free-ranging female Iberian wolf, 2-4 years-old and $30 \mathrm{~kg}$ in weight, was found injured in a trap in February 2012 in the northwest region of Portugal ( $41^{\circ} 55^{\prime} \mathrm{N} 8^{\circ} 15^{\prime} \mathrm{W}$ ), with a suspected fracture of its right thoracic limb. The animal was immobilized by dart sedation with ketamine (Imalgene ${ }^{\circledR}$, Merial, France) $(4.0 \mathrm{mg} / \mathrm{kg}$ ) and medetomidine (Domitor ${ }^{\circledR}$, Merial, France) $(0.8 \mathrm{mg} / \mathrm{kg})$ based on the weight of an adult wolf, and immediately transported to the Veterinary Hospital of UTAD in Vila Real, Portugal. The animal was anesthetized by IM administration of morphine (Morphine $2 \%{ }^{\circledR}$, B. Braun, Germany) $(0.2 \mathrm{mg} / \mathrm{kg})$, ketamine $(1 \mathrm{mg} / \mathrm{kg})$, (Midazolam B. Braun, B. Braun, Germany) midazolam $(0.2 \mathrm{mg} / \mathrm{kg})$ and dexmedetomidine (Dexdomitor ${ }^{\circledR}$, Zoetis, Finland) $(0.01 \mathrm{mg} / \mathrm{kg})$. Propofol (Propofol-Lipuro $2 \%{ }^{\circledR}$, B. Braun, Germany) (EV bolus) was used for endotracheal intubation and isoflurane $1.5 \%$ to $2 \%$ in oxygen for maintenance.
The wolf presented $39.2^{\circ} \mathrm{C}$, normal mucous membranes, a heart rate of $120 / \mathrm{min}$ and mild dehydration. Hematocrit and blood biochemistry were normal except for aspartate aminotransferase (AST) which was elevated (309 U/L) (Kreeger 2003) with a suspected early stage of rhabdomyolysis due to high AST values and mild coloured urine.

A comminuted radial fracture associated to an ulnar diaphyseal fracture was confirmed (Fig.1A). Therefore, following a lateral approach, a prompt fracture reduction and fixation was performed by intramedullary (IM) Steinmann pin in ulna and an 10 holes 3.5mm DCP (Dynamic Compression Plate) plate (AESCULAP $^{\circledR}$, B. Braun, Germany) was contoured to the cranial aspect of the radial diaphysis for application in a buttress function for radius stabilization with a reducible fragment stabilized through a $2.7 \mathrm{~mm}$ lag screw (Fig.1B). A cancellous bone autograft was loosely packed directly along the fracture lines before wound closure. The wound was then closed in three-layers using a 0 or 2.0 mid-term synthetic absorbable monofilament suture - glyconate (Monosyn ${ }^{\circledR}$, B. Braun, Germany): the deep antebrachial fascia and the superficial/subcutaneous fat tissue with interrupted cruciate sutures pattern and the skin with a continuous subcuticular suture pattern.

In the immediate post-operative period the wolf was kept in a metal cage $(115 \times 70 \times 70 \mathrm{~cm}$ in length, depth and height, respectively) inside the hospital facilities for easier handling and restriction of movement, with a central division allowing cleaning procedures without removing the animal. The surrounding area was shielded from the wolf's direct vision and the cage sealed against noise.

During these first days the wolf was kept under Ringers Lac-

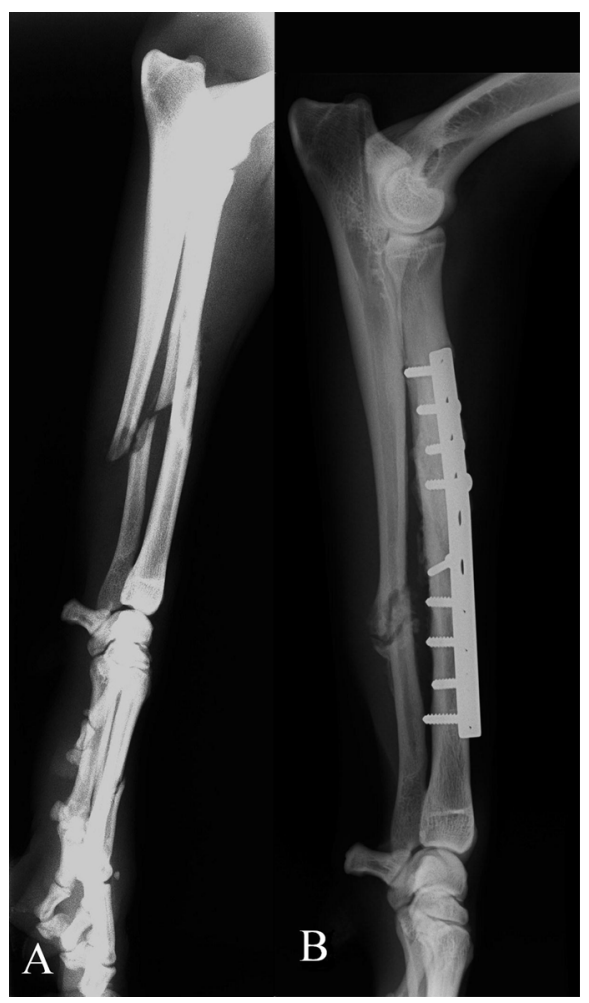

Fig.1. Radiographic images of the diaphyseal radial comminuted fracture associated to a midshaft short oblique ulnar diaphyseal fracture of the right thoracic limb in the (A) pre-operative period, (B) in the immediate post-operative period, and (C) at the 10th post-operative week when the wolf was released into the wild. 
tate (Labesfal, Portugal) $(5-10 \mathrm{ml} / \mathrm{kg} /$ hour SC) and different food was offered: high calorie dog food $\left(\mathrm{a} / \mathrm{d}^{\circledR}\right.$ Canine/Feline Critical Care, Hill's ${ }^{\circledR}$ Prescription Diet ${ }^{\circledR}$, USA), meat, liver and small freshly slaughtered rodents and rabbits. Due to the wolf's reluctance to eat, high calorie dog food and minced meat and liver softened with water and electrolytes was inserted into the wolf's mouth through a syringe attached to a tube to promote some food ingestion. On days 2 and 4, AST had decreased (251U/L), with presenting all other blood parameters and standard urine type II presenting as normal. Post-operative medication consisted of cefovecin (Convenia ${ }^{\circledR}$, Zoetis, USA) (8mg/kg SC day 1), clindamicine (Clincina ${ }^{\circledR}$, Labesfal, Portugal) $(10 \mathrm{mg} / \mathrm{kg}$ PO BID or SC days 2 to 10 ) and carprofen (Rimadyl ${ }^{\circledR}$, Pfizer Animal Health) (2.2mg/ $\mathrm{kg}$ PO day 2 to 14) and deworming with an association of $165 \mathrm{mg}$ praziquantel, $504 \mathrm{mg}$ pyrantel and $525 \mathrm{mg}$ febantel (Drontal ${ }^{\circledR}$ Plus XL, Bayer, UK) (1 tablet PO day 5).

At day 6 the animal started to eat by itself, so it was moved to a larger cage $(180 \times 70 \times 85 \mathrm{~cm})$ and at day 25 to an exterior chamber $(5.14 \times 1.85 \times 2.65 \mathrm{~m})$, using the same sedation method and unrestricted ambulation was allowed after this period. An X-ray exam of the operated limb and abdomen were obtained at that time. This chamber was adapted especially for this wolf, consisting of four brick walls with a door, a peephole for feeding and another for shooting anesthetics darts. Half of the area of the ceiling consisted of a metalized net and the other half was covered. A surveillance camera with night vision allowed evaluating the behavior of the wolf and the progressive use of the operated limb. In this chamber, the wolf usually remained inactive during the day, feed-

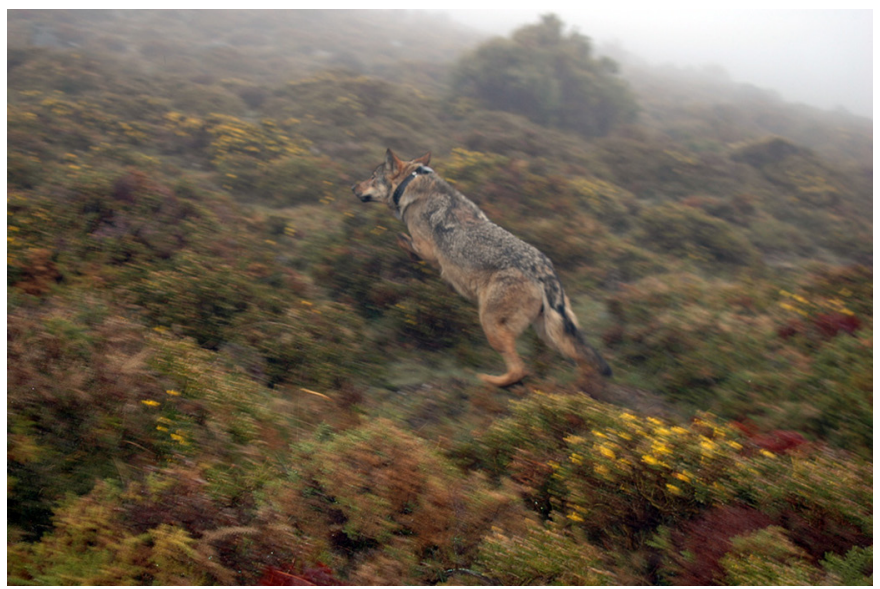

Fig.2. Release of the Iberian Wolf (Canis lupus signatus) at the 10th post-operative week after its successful rehabilitation, fitted with a GPS collar for post-release monitoring $\left({ }^{\odot}\right.$ Ricardo Brandão).

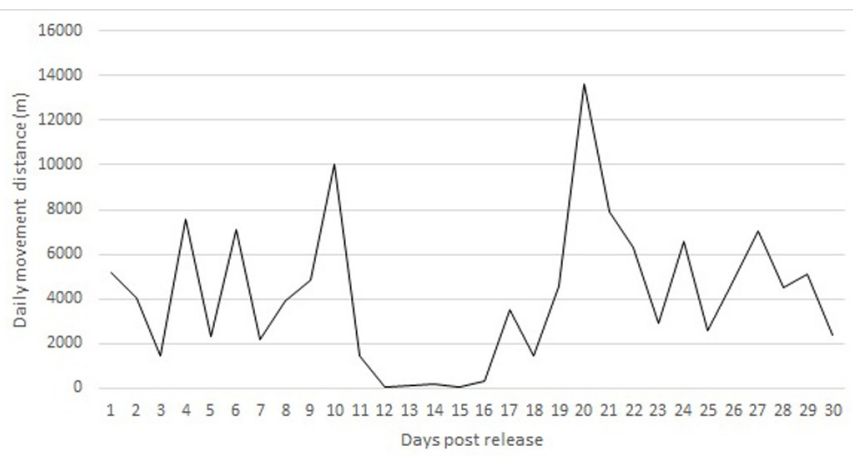

Fig.3. Daily movement distances covered by the injured wolf during the first 30 days after its release. ing only at night after all human activity ceased in the center. Food intake increased to a maximum of $1.5 \mathrm{~kg}$ of meat with bone per day and water was provided ad libitum. The wolf started to weight bearing cautiously the treated limb around the $3^{\text {rd }}$ post-operative week and supported its full weight on the right thoracic limb between the $6^{\text {th }}$ and $8^{\text {th }}$ post-operative weeks.

From the $8^{\text {th }}$ post-operative week, the wolf started to make repeated attempts to escape during the night, trying to jump over the wire netting and to destroy the top metallic mesh with the teeth, and to scrape the cement coating floor of the outdoor housing place. Since at this time point the general animal's status despite its continuous stress, was regular, as well as the fracture healing process, and to prevent the animal from hurting himself during these escape attempts, it was decided to release the wolf back in the wild around the $10^{\text {th }}$ post-operative week (day 66). After dart sedation, an X-ray exam was performed to confirm the fracture healing and the ulna IM pin was removed (Fig.1C) to minimize the possibility of triceps tendon injury caused by the proximal pin point, and after a small incision in the skin over it, and the animal transported to the original capture location for release. A GPS telemetry collar (Model Pro Light, Vectronic Aerspace GmBh, Berlin, Germany), was deployed on the wolf, which showed that after release in the wild (Fig.2) the animal covered increasingly large distances and areas, confirming a complete recovery of its right thoracic limb (Fig.3). The wolf was monitored for a total of 343 days (approximately 11 months), travelling a total distance of $2709 \mathrm{~km}$ with a daily average distance of $8 \mathrm{~km}$ (maximum $19 \mathrm{~km}$; minimum $0 \mathrm{~km}$ ) and covering a total area of $750 \mathrm{~km}^{2}$ (Rio-Maior et al. 2016, in publication). Approximately one year after being released into the wild the wolf was illegally shot, weighting $33.8 \mathrm{~kg}$ and presenting a favorable overall physical and health status at the time of death.

\section{DISCUSSION AND CONCLUSION}

The current literature provides scarce information about treatment of traumatic skeleton lesions on adult free-ranging wolves and post-operative care best suited to a musculoskeletal trauma in this species. In this clinical case a freeranging female Iberian wolf was found with a traumatic injury of its right thoracic limb. The animal's inability to support the affected limb associated to a visible instability and the limb swelling gave strong suspicious of a possible situation of a fracture of the radius and ulna. For these reasons, the animal was chemically immobilized as described and immediately transported by car under sedation and in a restraint-cage to Veterinary Hospital from UTAD for submission to fracture evaluation and stabilization. The animal arrived still under sedation and was put under Ringers Lactate EV infusion in the right medial saphenous vein. A thorough clinical examination, routine hematological and biochemical analysis and X-ray exams to the affected thoracic limb, thorax and abdomen were performed after the animal has been anesthetized. The pre-operative radiographic exams confirmed a compound fracture of the right thoracic limb composed by a middle-diaphyseal radial comminuted fracture associated to a midshaft short oblique ulnar diaphyseal fracture. Because of the risk of an exposed fracture to infection and the impossibility of a conservative stabilization management after the animal' anesthetic recover, it was decided to perform immediate surgical stabilization.

The comminuted pattern of this fracture made it unsuitable for IM pin and cerclage wire repair with requires ana- 
tomic reconstruction of the bone fragments. Also radius is not as amenable to IM pin fixation as the other long bones as it is relatively straight and covered at both extremities by articular cartilage and the bone marrow cavity is craniocaudal diameter (Piermattei et al. 2006). External skeletal fixation could be considered a good option in small companion animals (dog, cat) but for this case it would be a poor surgical treatment option due to the postoperative management of the external fixator frame in a wild aggressive animal (Martinez \& DeCamp 2012). So, bone plating should be the internal fixation technique of choice for this clinical case since cranial placement of the plate has been the most widely used method for all diaphyseal radial fractures, because it is easily accessible and provides a broad and only slightly curved surface (Harrison 1984, Johnston et al. 2012).

The fracture stabilization technique was selected according the recommendation of Piermattei et al. (2006) and a lateral approach to the shaft of radius was chosen since the positioning of the animal in lateral recumbency was more convenient to access simultaneously the shaft of radius and ulna and for the posterior obtainment of autogenous cancellous bone graft from the right proximal humerus (Piermattei \& Johnson 1993). In a first step, the ulnar fracture was reduced and fixated with an intramedullary Steinmann pin applied by retrograde insertion in support of the radial fixation and secondly, the radial fracture was reduced with resource to bone-holding forceps and DCP compression plate in a buttress function with a reducible fragment of the comminuted radial fracture stabilized through a $2.7 \mathrm{~mm}$ lag screw before the application of the bridging plate.

During the post-operative period, the sequential radiographic results confirmed good progression of the fracture healing process. The biologic assessment selected for this fracture stabilization with an internal bridging osteosynthesis, minimizing the attempt to reduce the bone fragments, and the application of an autogenous cancellous bone graft was found favourable for the successful outcome of this case. This biological osteosynthesis option, associated to the animal's movement control during the first post-operative weeks, surely helped reducing the imposed stress on the bone plate and consequently diminishing the probability of an implant failure during the fracture healing process.

During the post-operative period, great importance was also given to the wolf feeding, hydration, analgesia, bandages and size of the cages, increasing the dimensions as the handling of the animal was decreased. The interventions that involved direct handling were always made under chemical restraint using a combination of morphine, dexmedetomidine and ketamine administered IM through dart. The animal was examined daily and its welfare monitored during the entire duration of the indoor and outdoor housing period.

Our experience with this clinical case has shown that internal osteosynthesis of the bone fracture and minimal interaction with humans after the intensive care phase were good options and promoted the animal's spontaneous intake of food and reduced stress. However, the risk of injury derived from attempts to escapes was high, so the post-operative period was kept to a minimum, so early return to the wild was recommended. In fact, reducing stress is a key factor for the success rehabilitation of similar cases. The potentially adverse effects of stress on animal well-being and survival have long been recognized (Sapolsky 1990, Teixeira et al. 2007), and should be a major focus for wildlife researchers. Captivity period must be reduced to a minimum in order to avoid stress with additive or cumulative effects on animals (Sapolsky 1990). In a process of capture-captivity-release there are many potential sources of stress: capture, captivity, veterinary examinations, transportation from/to nature, release and adaptation to the natural environment, which includes the social adaptation to the conspecifics already established in their territories and the physical fitness for hunting. In all these phases, it should be guaranteed an extreme care in order to reduce external stress factors on the injured animal.

The successful experience obtained with this case could constitute acquired knowledge for the recuperation of similar clinical cases involving free-ranging wolves and other large carnivores, which becomes highly relevant, mainly for two reasons; a conservation perspective for recovering potential breeders in endangered populations or for an ethical point of view to prevent an often long and traumatic captivity for wild-born adult wolves.

Acknowledgements.- The authors thank Pablo Sierra, Nuria Fandos and Mónia Nakamura for their help during the rehabilitation process, Maurino R. Luís for performing the anesthetic and sedation protocols, Joana M. Valente and Carlos A. Viegas for their technical support to the wolf in the post-operative period. The authors also thank the University of Trásos-Montes e Alto Douro for their financial support for the treatment and rehabilitation of this wolf, and ACHLI/Vento Minho for their GPS telemetry monitoring after release. The capture, handling and marking with a GPS collar of this wolf was conducted under a legal permit for research purposes issued by the National Nature Conservation Authority. This is the paper no.6 from the Iberian Wolf Research Team (IWRT).

\section{REFERENCES}

Álvares F. 2004. Status and conservation of the Iberian Wolf in Portugal. Wolf Print 20:4-6.

Arnemo J.M., Ahlqvist P., Andersen R., Bernsten F., Ericsson G., Odden J., Brunberg S., Segerstrom P. \& Swenson J.E. 2006. Risk of capture-related mortality in large free-ranging mammals: Experiences from Scandinavia. Wildl. Biol. 12:109-113.

Blanco J.C. \& Cortés Y. 2009. Ecological and social constraints of wolf recovery in Spain, p.41-66. In: Musiani M., Boitani L. \& Paquet P.C. (Eds), A New Era for Wolves and People: wolf recovery, human attitudes and policy. University of Calgary Press, Energy, Ecology and the Environment Series no.2, Alberta, Virginia.

Bush M., Neeley L.M. \& Gray C.W. 1974. Repair of a non-union radius and ulna fracture in a Timber Wolf. Zool. Garten N.F., Jena, 45:S78-80.

Frame P. \& Meier T. 2007. Field-assessed injury to wolves captured in rubber-padded traps. J. Wildl. Manage. 71:2074-2076.

Harrison J.W. 1984. Fractures of the radius and ulna, p.144-151. In: Brinker W.O., Hohn R.B. \& Prieur W.D. (Eds), Manual of Internal Fixation in Small Animals. Springer-Verlag, New York.

Johnston S.A., Von Pfeil D.J.F., Dejardin L., Weh M. \& Roe S. 2012. Internal fracture fixation, p.576-607. In: Tobias K.M. \& Johnston S.A. (Eds), Veterinary Surgery: Small Animals. Vol. 1, Elsevier Saunders, St. Louis, Missouri.

Kielbowicz Z., Biezynski J. \& Kuryszko J. 2003. Osteosynthesis of a wolf 
tibial fracture using the ZESPOL technique. Medycyna Wet. 59:61-63.

Kreeger T.J. 2003. The internal wolf: Physiology, pathology and pharmacology, p.192-217. In: Mech L.D. \& Boitani L. (Eds), Wolves: Behavior, Ecology and Conservation. University of Chicago Press, Chicago, Illinois.

Martinez S.A. \& DeCamp C.E. 2012. External skeletal fixation, p.608-627. In: Tobias K.M. \& Johnston S.A. (Eds), Veterinary Surgery: Small Animals. Vol.1, Elsevier Saunders, St Louis, Missouri.

Mech L.D. \& Boitani L. 2003. Wolves: behavior, ecology and conservation. University of Chicago Press, Chicago, Illinois. 472p.

Piermattei D.L., Flo G.L. \& DeCamp C.E. 2006. Fractures of the radius and ulna, p.359-381. In: Brinker W.O., Piermattei D.L. \& Flo G.L. (Eds), Handbook of Small Animal Orthopedics and Fracture Repair. 4th ed. Saunders Elsevier, St Louis, Missouri.
Piermattei D.L. \& Johnson A. 1993. Approach to the shaft of the radius through a lateral incision, p.200-203. In: Piermattei D.L. \& Johnson K.A. (Eds), An Atlas of Surgical Approaches of the Bones and Joints of the Dog and Cat. 3rd ed. W.B. Saunders Company, Philadelphia, Pennsylvania.

Rio-Maior H., Beja P., Nakamura M., Santos N., Brandão R., Sargo R., Dias I., Silva F. \& Álvares F. 2016. Rehabilitation and post-release monitoring of two wolves with severe injuries. J. Wildl. Manage. DOI: 10.1002/ jwmg.1055 (In publication, as Research Note).

Sapolsky R.M. 1990. Stress in the wild. Scient. Am. 262:106-113.

Teixeira C.P., de Azevedo C.S., Mendl M., Cipreste C.F. \& Young R.J. 2007. Revisiting translocation and reintroduction programs: the importance of considering stress. Anim. Behav. 73:1-13.

Wobeser G. 1992. Traumatic, degenerative, and developmental lesions in wolves and coyotes from Saskatchewan. J. Wildl. Dis. 28:268-275. 